\title{
Determination of in Vitro Antioxidant Enzyme Capacity and Oxidative Stress Levels in Mazı Meşesi (Quercus infectoria)
}

\author{
İlter Demirhan ${ }^{1, a, *}$, Büşra Çitil ${ }^{2, b}$, Mehmet Özyurt ${ }^{2, c}$, Meltem Güngörr ${ }^{3, d}$, Erkan Öner $^{4, e}$, Ergül Belge Kurutaşs,f \\ ${ }^{1}$ Electronics-Automation Department, Vocational School of Health Services, Harran University, 63050 Şanliurfa, Turkey \\ ${ }^{2}$ Department of Medical Biochemistry, Faculty of Medicine, Kahramanmaraş Sütçü Imam University, 46050 Kahramanmaraş, Turkey \\ ${ }^{3}$ Department of Medical Biochemistry, Faculty of Medicine, Sanko University, 27090 Gaziantep, Turkey \\ ${ }^{4}$ Department of Basic Biochemistry, Faculty of Pharmacy, Mersin University, 33110 Mersin, Turkey
}

*Corresponding author

\section{A R T I C L E IN F O A B S T R A C T}

Research Article

South East Anatolia Region has a large genetic plant diversity due to its physical and different climatic charesteristics. These plants are potential sources of antioxidants that prevent oxidative stress caused by oxygen and photons. In recent years, it has become important to study the antioxidant capacity of many molecules found naturally in foods and biological systems. The reason

Received : $10 / 02 / 2021$

Accepted : 10/03/2021 for this is that it is believed that when the consumption of food rich in antioxidants is increased, the risk of developing different degenerative diseases will be reduced. In this study, it was aimed to measure the antoxidant capacity of Quercus infectoria, G.olivier gal seeds grown in Southeastern Anatolia. $Q$. infectoria gal seeds from Sanliurfa province were used in our study. $Q$. infectoria gal seeds were extracted with water, ethanol and methanol and then antioxidant enzyme activities (catalase and superoxide dismutase) and malondialdehyde levels, which are indicators of oxidative

Keywords:

Quercus infectoria gal stress were determined by spectrophotometric methods. It was found that the antioxidant capacity (catalase and superoxide dismutase activities) of extracts obtained from ethanol and methanol were higher and their malondialdehyde levels were statistically lower than those obtained from water. Catalase Superoxide dismutase Malondialdehyde Antioxidants However, it was determined that there was no statistically significant difference between the antioxidant capacity and malondialdehyde levels of the extracts obtained from methanol compared to the extracts obtained from ethanol. It has been concluded that $Q$. infectoria gal seed has a effective antioxidant effect. In addition, it was observed that extracts obtained from ethanol and methanol have higher antioxidant capacity than extracts obtained from water.

ilterdemirhan@harran.edu.tr mehmetozyurtt@gmail.com erkanoner0803@gmail.com

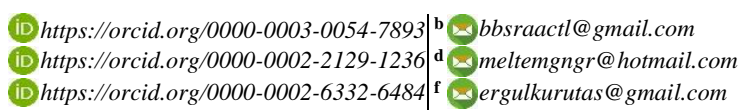

(D) https:///orcid.org/0000-0001-8168-4392 (iD https://orcid.org/0000-0002-8062-1610 (iD) https://orcid.org/0000-0002-6653-4801

(c) (1) () Te This work is licensed under Creative Commons Attribution 4.0 International License

\section{Introduction}

Thanks to the pharmacological compounds and bioactive substances found in the structure of the plants, it is forms the origin of many drugs used today (Sevindik et al., 2017). Therapeutic use in plants BC.it is based on the Mesopotomian civilization in the 5000s and it was determined that approximately 250 herbal drugs were used (Mohammed et al., 2018). It is reported by World Health Organization that the treatment with herbs will increase all over the World by the coming years (WHO, 2015). For this reason, obtaining and evaluating the main active ingredients of the extracts obtained from plants is of great importance in terms of economy and health.

The Thuja (Q. infectoria), which spread in the Southeastern Anatolia Region in our country, is a plant belonging to the Fagaceae family. Q. infectoria is referred to as a oriental thuja in its varieties (Böhner, 1934).Thuja seeds are called gal. According to literature studies, gal extracts have used in many settlements as medicanal drugs for different purposes since ancient times. For example, it has been used in India for a long time to treat chronic diarrhea and söre throat (Camus, 1934). At the time of the ancient Greeks, Hippocrates prepared a special incense by mixing thuja seed with honey and oil. This incense has given succesfull results in the treatment of Hysteria for many years ((İnal.,1955).). The seeds of thuja called gal, are $1.5-2 \mathrm{~cm}$. spherical in diameter and randomly rough on top (Shresthka, 2014). In the southeastern Anatolia Region, thuja seeds have been used by local people for centuries to treat burn wounds. Powdered thuja seeds applied regularly burned area. 
Antioxidants are molucules responsible for reducing the formation of free radicals, ending radical reactions, neutralizing the formed radicals and removing damaged molecules (Machlin et al., 1985; Pehlivan et al., 2018). Free radicals can cause serious damage to the body if not neutralized (Yiğit, 2013; Sevindik, 2018). According to the researches, it has been determined that the consumption plenty of vegetables and fruits reduces the risk of developing diseases, there is a significant decrease in cardiovascular diseases, cancer cases and mortality rates (Arıduru, 2013).

In recent years, there have been about the use of antioxidant plants in areas such as medicine and food. These studies are still continuing intensively. The reason fort his is that the plants are very rich in terms of carotenoids, flavonoids and phenolic compounds, which are antioxidants, and these compounds do not have any side effects (Özkan, 2000; Salehi et al., 2019). Its known that the thuja used in this study is used by the public in the treatment of various diseases. Today, the raw materials of many drugs are composed of compounds synthesized by medicinal and aromatic plants. In literatüre searches, no in vitro study examining the antioxidant activity of thuja plant was found. For this reason, we aimed to measure the antioxidant anzyme activity of thuja plant and MDA levels, which are indicators of oxidative stress in methanol, ethanol and water extracts.

\section{Material and Method}

The seeds of thuja that grow naturally in the province of Sanliurfa in the Southeastern Anatolia Region were used. The fruit outer skins of all the samples were removed and dried in a thin layer under room conditions, out of sunlight. Then the samples were pulled in the mill and stored at room temperature until they were used.

\section{Extraction of Samples}

The cold extraction method applied by Fernández Agulló (2013) in the extraction of the samples was modified. In the extractions made with water, $10 \mathrm{~g}$ of sample was weighed and $100 \mathrm{~mL}$ of water was added on it. Then, after being kept in the shaking water bath at $60^{\circ} \mathrm{C}$ for 12 hours, the samples passed through the coarse filter and then through whatman 4 filter paper were centrifuged and the supernatant was taken and used as stock solution.

To obtain extracts using ethanol and methanol as solvents, $10 \mathrm{~g}$ of sample was weighed, $90 \mathrm{~mL}$ of solvent and $10 \mathrm{~mL}$ of water were added. Then, the samples passed through the coarse filter and then through whatman 4 filter paper were centrifuged, and finally the supernatant was taken under vacuum until the ethanol or methanol was removed according to the solvent used in the rotary evaporator. The extract-water mixture obtained was used as the stock solution. Biochemical analyzes (SOD, superoxide dismutase; CAT, catalase and MDA, malondialdehyde) were performed on all three extracts (ethanol, methanol and water) obtained.

\section{Determination of SOD Activity}

SOD enzyme in tissue samples was measured according to the method described by Fridovich. SOD accelerates the dismutation of toxic superoxide radicals into hydrogen peroxide and molecular oxygen during oxidative energy production. In this method, the red colored formazan dye formed by 2- (4-iodophenyl) -3- (4-nitrophenol) -5 phenyltetrazolium chloride (pyodonitrotetra zolium violet: NT) produced by the use of xanthine and xanthine oxidase with a wavelength of $505 \mathrm{~nm}$. It is based on the reading of optical density (OD). The OD of the red color formed decreases according to the color formed in the absence of SOD, and SOD activity is measured by determining the difference here (Fridovich, 1974).

\section{Determination of CAT Activity}

CAT activity was measured by the Beutler method. It was determined by measuring the decrease in hydrogen peroxide concentration at $230 \mathrm{~nm}$. CAT activity was expressed as $\mathrm{U} / \mathrm{mg}$ protein. CAT catalyzes the breakdown of hydrogen peroxide. The rate of degradation of hydrogen peroxide by CAT was measured spectrophotometrically using hydrogen peroxide's absorption of light at $230 \mathrm{~nm}$ (Beutler, 1984).

\section{MDA Levels}

For each plant extract; MDA level was determined using the Ohkawa method (Ohkawa, 1979). It is based on the principle of forming a pink colored complex with MDA, which is the secondary product of lipid peroxidation, which occurs as a result of incubation of the sample with thiobarbituric acid (TBA) at pH 3.4 under aerobic conditions. The color intensity formed is directly proportional to the MDA concentration in the environment; It was evaluated spectrophotometrically at $532 \mathrm{~nm}$.

\section{Results}

As seen in Table 1, the antioxidant capacity (CAT and SOD activities) of extracts obtained from ethanol and methanol are higher than those obtained from water $(\mathrm{P}<; 0.05)$. Moreover, the highest CAT and SOD activities were found in methanol extracts $(\mathrm{P}<0.05)$. It was determined that the MDA levels of extracts obtained from ethanol and methanol were statistically lower than those obtained from water $(\mathrm{P}<0.05)$ (Figure 1). However, it was determined that there was no statistically significant difference between MDA levels of extracts obtained from methanol compared to extracts obtained from ethanol $(\mathrm{P}>0.05)$.

Table 1. CAT and SOD activity in extracts obtained with ethanol, methanol, water

\begin{tabular}{l|cl}
\hline \multicolumn{1}{c|}{ Groups } & $\begin{array}{c}\text { CAT Activity } \\
\text { Average } \pm \text { SD }\end{array}$ & \multicolumn{1}{c}{$\begin{array}{c}\text { SOD Activity } \\
\text { Average } \pm \text { SD }\end{array}$} \\
\hline Ethanol Group & $558.05 \pm 230.31^{* *}$ & $76.55 \pm 17.97 * * *$ \\
Methanol Group & $652.93 \pm 179.68^{* *}$ & $138.73 \pm 35.10^{* * *}$ \\
Water Group & $219.47 \pm 44.18^{*}$ & $40.33 \pm 9.80^{* * *}$ \\
\hline
\end{tabular}

CAT: catalase; SOD: superoxide dismutase; SD: Standard deviation

* CAT activity was statistically significantly higher in ethanol and methanol compared to water $(\mathrm{P}<0.05)$.

$* *$ No significant differences were found between methanol and ethanol extracts in terms of CAT activity $(\mathrm{P}>0.05)$.

*** While SOD activity showed significant differences between methanol, ethanol and water extracts $(\mathrm{P}<0.05)$, the highest SOD activity was found in methanol extract $(\mathrm{P}<0.05)$. 


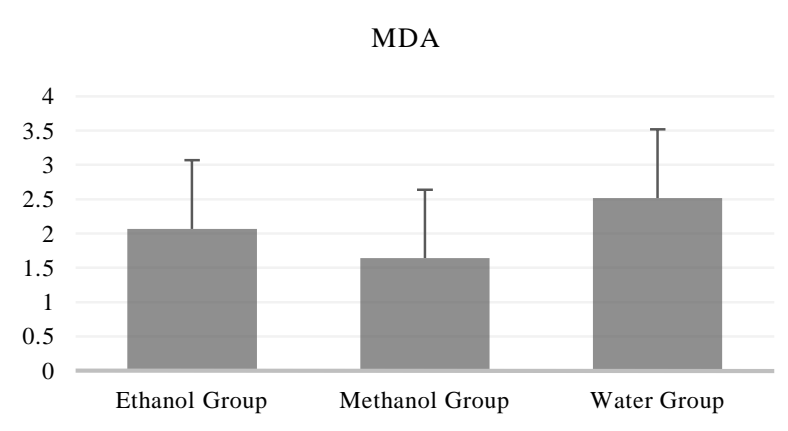

Figure 1.MDA levels in extracts obtained with ethanol, methanol, water

\section{Discussion}

As in all countries of the world, medicinal plants have been used by the public for centuries in the treatment of diseases in our country. Today, herbs and herbal medicine raw materials make up $25 \%$ of prescription drugs. The antioxidant effects of plants and their important properties for human health have been investigated in laboratories since 1926. In recent years, many studies have been done on the antioxidant effects of medicinal plants (Salehi et al., 2020a). Nowadays, herbs and herbal medicine raw materials constitute a large part of medicines used in treatment. The inadequacy of synthetic drugs and therapeutic agents against the increasing diseases in recent years and the detection of their side effects have increased the necessity of using natural products. For this purpose, plants have been investigated in terms of biochemical, microbiological and pharmacological aspects, and even in terms of plant defense mechanisms in recent years when biological warfare is on the agenda (Kalaycığlu and Öner, 1994; Mohammed et al., 2020). There are many different phenolic compounds found in all plant metabolisms as secondary metabolites that are thought to play a role in protecting the plants against some pests (Saldaml, 2007; Mohammed et al., 2019). Phenolic compounds defined as secondary metabolism products of plants are widely found in plants and today the structure of thousands of phenolic compounds has been defined (Kafkas et al., 2006). Newly defined phenolic compounds are continuously added to these every day. Phenolic compounds can be found in fruits, vegetables, seeds, flowers, leaves, branches and stems of plants (Coşkun, 2006; Aydın et al., 2007).

These metabolites, which are generally in the class of phenolic compounds, can show their antioxidant activities in the human body when consumed by humans through the diet (Chaudiere, 1999). For this reason, in recent years, people have been encouraged to take natural food-derived antioxidants. On the other hand, the use of plant extracts containing abundant antioxidant compounds (Karagözler et al., 2008) as a preservative in the food industry is also a common practice in recent years. However, in food technology, synthetic antioxidants are also used as additives to ensure the long-term durability of foods. Although these synthetic antioxidants have very high protective properties, there is also controversy that they may be harmful to human health due to their unnatural nature (Pokorny, 2007). It has been reported in various studies that the antioxidant properties of natural antioxidants are related to their molecular structure (Rice-
Evans et al., 1997; Pannala et al., 2001; Apak et al., 2007; Salehi et al., 2020b).

There are many studies showing that Q. infectoria gal seeds contain ellagic acid (Quideau, 2009). In some studies on ellagic acid, it has been observed that it has antioxidant, antiviral, anticarcinogenic, antimutagenic and antiinflammatory properties (Singh, 2005). Studies conducted today show that defense systems originating from the organism alone are not sufficient in removing oxygen radicals. Especially in researches, it has been determined that antioxidants taken from outside can be quite effective against oxidative damages in the organism (Kurutaş, 2015). An increasing number of scientific studies show that nutritional components have positive effects on health and contribute to the prevention of diseases such as cardiovascular diseases, cancer and osteoporosis (Kurutaş, 2015). Phytochemicals found in vegetables and fruits that we consume frequently are effective by capturing oxidants as well as by regulating the activation of detoxifying enzymes, stimulation of the immune system, cell proliferation and apoptosis, hormone metabolism, and antibacterial and antiviral effects (Kurutaş, 2015).

Q. infectoria plant belongs to the group of plants exposed to high levels of oxidative stress. On the other hand, the presence of a powerful antioxidant that protects the plant has been revealed by various researchers (Dicko, 2006). Kaur et al. (2008) reported that as a result of the incubation of Q. infectoria gal extract with macrophages, cells were protected against oxidative stress and seeds showed a high level of antioxidant activity. In this study, it can be said that Q. infectoria gal seeds show high levels of antioxidant activity (SOD and CAT) due to ellagic acid and polyphenol compounds.

When the literature is searched, studies on antioxidant activity measurement specific to $\mathrm{Q}$. infectoria gal are very few. Today, antioxidant measurements can be made using different methods. In our study, we aimed to obtain results on antioxidant enzyme activities using spectrophotometric methods. In this sense, SOD and CAT activities and MDA levels were measured as oxidative stress parameters in the plant. When SOD and CAT enzyme activities were evaluated, it was observed that Q. infectoria gal plant seed had high antioxidant capacity. This result we found supports the literature studies. Unver et al. (2008) in a study of antioxidant activity of some plants with application in medicine, Turkey, acetone, ethanol, was determined using various solvents such as water. According to the data obtained, it was found that the free radical scavenging efficiency of plant extract, whose solvent is water, is higher than extracts whose solvents are ethanol and acetone (Unver et al., 2008). In our study, we used methanol, ethanol and water. Because methanol, ethanol and water are a universal solvent traditionally used to extract most plant products with antioxidant activity. Among the solvents we prepared using methanol, ethanol and water, the highest antioxidant capacity was found in the methanol extract, while the lowest acthioxidant activity was found in the extract we prepared with water. It has been observed that the active substances existing in plants change depending on the solvent used.

In addition, it is thought that determination of possible active substances in our plant and elucidation of their chemical structures will be pharmacologically important. 
Today, the risk of chronic and degenerative diseases is increasing day by day due to changing life conditions and eating habits. From this point on, reducing this risk is one of the main issues of the scientific world. In this context, plants and their biological activities are used in the development of new drug and food formulations. As a result of our work on this basis, methanol extract exhibited effective antioxidant effects. Q. infectoria gal can be considered as an important candidate for natural agents, as it is important to identify safe and effective functional agents.

\section{References}

Aridiru R, Arabacı G. 2013. Ciğertaze otu'nun antioksidan aktivitesinin belirlenmmesi, SAÜ. Fen Bilimleri Dergisi, 17(2): 241-246.

Beutler E. 1984. Superoxide dismutase. In Beutler E (Editor). Red Cell Metabolism. A Manual of Biomedical Methods, 83-85.

Böhner K. 1934. Geschichte der Cecidologie, Bd.I,Mittenwald (Bayern).

Camus A. 1934. Tom, I. Les chennes, Paris.

Chaudiere J, Ferrari-Iliou R. 1999. Intracellular Antioxidants: From chemical to biochemical mechanisms. Food and Chemical Toxicology, 37: 949-962.

Dicko MH, Gruppen H, Traoré AS, Voragen AGJ, van Berkel WJH. 2006. Phenolic Compounds and Related Enzymes as Determinants of Sorghum for Food Use. Biotechnology and Molecular Biology Review, 1(1): 21-38.

Fridovich I. 1972. Superoxide radical and superoxide dismutase. Accounts of Chemical Research, 5(10): 321-326.

İnal S. 1955. Meşe (Quercus) hakkında etimolojik ve tarihi etüdler. İstanbul Üniversitesi Orman Fakültesi Dergisi, 5(1): 100-111.

Kafkas E, Bozdoğan A, Burgut A, Türemiş N, Kargı S, Cabaroğlu T. 2006. Bazı Üzümsü Meyvelerde Toplam Fenol ve Antosiyanin İçerikleri. II. Ulusal Üzümsü Meyveler Sempozyumu, Tokat, Türkiye, 309-12.

Kalaycıŏglu A, Öner C. 1994. Bazı bitki ekstraktlarının antimutajenik etkilerinin Ames Salmonella test sistemi ile araştırılması. Turkish Journal Botany, 18: 117-122.

Karagözler AA, Erdağ B, Emek YÇ, Uygun DA. 2008. Antioxidant activity and proline content of leaf extracts from Dorystoechas hastata. Food Chemistry, 111: 400- 407.

Kaur G, Athar M, Alam MS. 2008. Quercus infectoria galls possess antioxidant activity and abrogates oxidative stressinduced functional alterations in murine macrophages. Chemico-Biological Interactions, 171(3): 272-282.

Kurutas EB. 2015. The İmportance Of Antioxidants Which Play The Role in Cellular Response Against Oxidative/Nitrosative Stress: Current State. Nutrition Journal, 15(1): 1-22.

Machlin LJ, Bendich A. 1987. Free radical tissue damage: protective role of antioxidant nutrients. Journal of the Federation of American Societies for Experimental Biology, 1: 441- 445.

Mohammed FS, Akgul H, Sevindik M, Khaled BMT. 2018. Phenolic content and biological activities of Rhus coriaria var. zebaria. Fresenius Environmental Bulletin, 27(8): 56945702.

Mohammed FS, Karakaş M, Akgül H, Sevindik M. 2019. Medicinal properties of Allium calocephalum collected from Gara Mountain (Iraq). Fresen Environ Bull, 28(10): 7419-7426.

Mohammed FS, Şabik AE, Sevindik E, Pehlivan M, Sevindik M. 2020. Determination of Antioxidant and Oxidant Potentials of Thymbra spicata Collected from Duhok-Iraq. Turkish Journal of Agriculture-Food Science and Technology, 8(5): 1171-1173.
Ohkawa HNO. 1979. Assay of lipid peroxides in animal tissues by thiobarbituric acid reaction. Annals of Biochemistry, (95): 351-358.

Özkan A, Gündüz G, Çıplak B, Fışkın K. 2000. Kimyasal mücadele uygulanmış Dociostaurus Maroccanus epidemik populasyonundan alınan örneklerde antioksidan enzim aktiviteleri. Turkish Journal of Biology, 24: 141-149.

Pehlivan M, Mohammed FS, Sevindik M, Akgul H. 2018. Antioxidant and oxidant potential of Rosa canina. Eurasian Journal of Forest Science, 6(4): 22-25.

Pokorny J. 2007. Are natural antioxidants better- and safer-than synthetic antioxidants? European Journal of Lipid Science and Technology, 109: 629-642.

Quideau S. 2009. "Chemistry and Biology of Ellagitannins". Hackensack, USA: World Scientific Publishing Co. Pte. Ltd.

Rice-Evans C, Miller N, Paganga G. 1997. Antioxi-dant properties of phenolic compounds. Trends In Plant Science, 2: $152-9$.

Saldamlı İ. 2007. Gıda Kimyası. Hacettepe Üniversitesi Yayınları, Ankara, 463-92.

Salehi B, Gültekin-Özgüven M, Kırkın C, Özçelik B, MoraisBraga MFB, Carneiro JNP, Bezerra CF, da Silva TG, Coutinho HDM, Amina B, Armstrong L, Selamoglu Z, Sevindik M, Yousaf Z, Sharifi-Rad J, Muddathir AM, Devkota HP, Martorell M, Jugran AK, Martins N, Cho WC. 2019. Anacardium plants: chemical, nutritional composition and biotechnological applications. Biomolecules, 9(9): 465.

Salehi B, Gültekin-Özgüven M, Kirkin C, Özçelik B, MoraisBraga MFB, Carneiro JNP, Bezerra CF, da Silva TG, Coutinho HDM, Amina B, Armstrong L, Selamoglu Z, Sevindik M, Yousaf Z, Sharifi-Rad J, Muddathir AM, Devkota AP, Martorell M, Jugran AM, Cho WC, Martins N. 2020. Antioxidant, antimicrobial, and anticancer effects of anacardium plants: an ethnopharmacological perspective. Frontiers in Endocrinology, 11: 295.

Salehi B, Selamoglu Z, Sevindik M, Fahmy NM, Al-Sayed E, ElShazly M, Csupor-Löffler B, Csupor D, Yazdi SE, SharifiRad J, Arserim-Uçar DK, Arserim EH, Karazhan N, Jahani A, Dey A, Azadi H, Vakili SA, Sharopov FA, Martins N, Büsselberg D. 2020. Achillea spp.: A comprehensive review on its ethnobotany, phytochemistry, phytopharmacology and industrial applications. Cellular and Molecular Biology, 66(4): 78-103.

Sevindik M, Akgul H, Pehlivan M, Selamoglu Z. 2017. Determination of therapeutic potential of Mentha longifolia ssp. longifolia. Fresen Environ Bull, 26(7): 4757-4763.

Sevindik M. 2018. Pharmacological properties of Mentha species. J Tradit Med Clin Natur, 7(2): 259.

Shrestha S, Kaushik V.S, Eshwarappa R.S, Subaramaihha R.S, Ramanna L.M, Lakkappa D.B. 2014. Pharmacognostic studies of insect gall of Quercus infectoria Olivier (Fagaceae). Asian Pac J Trop Biomed, 4(1): 35-39.

Singh RJA. 2005. Antimicrobial Activity of Some Natural Dyes. Dyes and Pigments, 66: 99- 102.

Ünver A, Arslan D, Çetinkaya Z, Özcan MM. 2008. Antimycotic activity of methanol extracts of sage (Salvia officinalis L.), Laurel (Laurus Nobilis L.) and Thyme (Thymbra spicata L.). J. Essential Oil Bearing Plants, 11: 90-95.

WHO. 2015. Connecting Global Priorities: Biodiversity And Human Health: A State Of Knowledge Review, ISBN 9789241508537.

Yigit NO, Dulluc A, Koca SB, Didinen BI. 2013. Effects of canola meal use instead of soybean meal in mirror carp (Cyprinus carpio, L. 1758) diet on growth and body composition. Tarim Bilimleri Dergisi, 19 (2): 140-147. 